\title{
LAS POETAS DE LA GENERACIÓN DEL 50 Y LA IMAGINERÍA INDUMENTARIA
}

\author{
SHARON KEEFE UGALDE
}

Texas State University su01@txstate.edu

RESUMEN: Este estudio indaga el imaginario del indumentario en la obra de poetas españolas de la Generación del 50. En una sociedad patriarcal, las mujeres aprenden a construir su apariencia de acuerdo con la mirada masculina controladora, lo cual lleva a una preocupación con el indumentario. Esta preocupación penetra la esfera femenina, incluyendo el imaginario de las mujeres poetas. Un análisis de textos de María Elvira Lacaci, María Benetyo, Blanca Sarasua, Francisca Aguirre, Pino Betancor, María Victoria Atencia y Elsa López revela que las imágenes del vestir se entretejen en una amplia gama temática: la metapoesía, el clasismo, la opresión femenina, la auto-representación y el linaje matriarcal.

PALABRAS CLAVE: Generación del 50, poesía femenina española, indumentario, mirada masculina, María Beneyto, María Victoria Atencia, María Elvira Lacaci.

* Este artículo se halla vinculado al Proyecto de Investigación del Plan Estatal "Poéticas del 50: proyecciones y diversificaciones", ref. FFI2013-41321-P (AEI/FEDER, UE). 


\section{MID-CENTURY WOMEN POETS OF SPAIN AND APPAREL IMAGERY}

ABSTRACT: This study examines clothing imagery in works by Spanish women poets of the Generation of the 1950s. In patriarchal society women learn to scrutinize their appearance to comply with the controlling masculine gaze. How they are viewed by men determines their identity and success in life. Thus, concerns with apparel permeate the feminine sphere and, not surprisingly, enter the imaginary of women poets. An analysis of texts by María Elvira Lacaci, María Benetyo, Blanca Sarasua, Francisca Aguirre, Pino Betancor, María Victoria Atencia, and Elsa López reveals that dress imagery is women into a broad thematic gamma: metapoety, class inequity, female oppression, self-representation, and matriarchal linage.

KEYWORDS: Spanish Generation of the 1950s, women's poetry, dress, masculine gaze, María Victoria Atencia, María Beneyto, Elvira Lacaci.

$\mathrm{A}$ pesar de un contexto socio-político de posguerra poco favorable a su exito, las poetas de la Generación del 50 logran ser innovadoras y precursoras del boom de la poesía femenina de la década de los 90. De una forma moderada e indirecta las veteranas de medio siglo se enfrentan con el encierro femenino en espacios y roles predeterminados y con la represión sexual. Por otra parte, reivindican las experiencias, prácticas y funciones de las mujeres y abordan temas metapoéticos, sociales y metafísicos. En el proceso de dejar constancia de sus perspectivas íntimas y colectivas, las poetas elaboran una imaginería indumentaria impactante y original. Este lenguaje figurativo se manifiesta en la poesía canónica —en "Vino, primero, pura" de Juan Ramón Jiménez, por ejemplo- pero las mujeres tienen una relación particular con las imágenes de la vestimenta. La exigencia milenaria impuesta por el domino de la mirada masculina de cuidarse la apariencia adscribe a la indumentaria femenina una significación fundamental para ellas. Las mujeres de la Generación del 50 descubren en esa relación histórica con la ropa una fuente para enriquecer la expresión poética.

\section{La mirada controladora}

Las observaciones del historiador del arte John Berger clarifican la relación de las mujeres con el vestir. Berger explica que en el patriarcado la jerarquía del poder se concentra en la mirada masculina. Como históricamente el destino de la mujer depende de un hombre - padre, hermano, marido- ella en todo momento y en cualquier situación necesita tener en cuenta cómo ellos la juzgarán. Las mujeres se sienten obligadas a escudriñar su propia apariencia porque al final cómo se las ve determina su éxito en la vida. Así para la mujer el acto de mirar se desdobla: el mirar es masculino y lo mirado (ella misma) es femenino. Berger describe las consecuencias de la mirada desdoblada:

Men act and women appear. Men look at women. Women watch themselves being looked at. This determines not only most relations between men and women but also the relation of women to themselves [...] Thus she turns herself into an object-and most particularly an object of vision: a sight (Berger, 1972: 47). ${ }^{1}$

Laura Mulvey reelabora las observaciones de Berger desde una perspectiva sicoanalítica, fundamentándose en el análisis del cine en vez de la pintura. Mulvey propone como base de la diferencia sexual el control de las imágenes, que ella relaciona con la mirada erótica masculina: "In a world ordered by sexual imbalance, pleasure in looking has been split between active/male and passive/female. The determining male gaze projects its phantasy on to the female figure which is styled accordingly"2 (Mulvey, 1999: 837). La codificación visual de la mujer acaba encerrada en el bina-

${ }^{1}$ Los hombres actúan y las mujeres aparecen. Los hombres miran a las mujeres. Las mujeres se contemplan a sí mismas mientras son miradas. Esto determina no sólo la mayoría de las relaciones entre hombres y mujeres, sino también la relación de las mujeres consigo mismas. [...] De este modo (ella) se convierte a sí misma en un objeto, y particularmente en un objeto visual, en una visión". Todas las traducciones al inglés de este artículo son de la autora.

2 "En un mundo ordenado por el desequilibrio sexual, el placer de mirar se divide entre activo/masculino y pasivo/femenino. La mirada masculina determinante proyecta sus fantasías en la figura femenina que construye su apariencia conforme con esa mirada".

UNED. REI, 5 (2017), pp. 47-69

ISSN 2340-9029 
rismo patriarcal erótica/pudorosa. En ambos casos la mirada masculina controla el cuerpo femenino.

El vestir como sistema semiótico comunica múltiples distinciones sociales: la etnia, la nacionalidad, la época histórica, la edad, la clase social, la profesión; pero, como recalca E. Crawley, la distinción más importante es la del género (cit. en Barnes y Eicher, 1993: 10). En la clasificación de la indumentaria es frecuente no destacar la preponderancia de lo visual, sino también del género sexual (Barnes y Eicher, 1993: 17). Antes que la palabra, la indumentaria anuncia la condición femenina. Como la identidad de la mujer depende de su apariencia, el armario se convierte en mueble esencial. El acto de abrirlo y probar varios trajes delante del espejo - los ojos masculinos - no se limita a las adolescentes. La ropa como elemento esencial de la esfera femenina invade los terrenos sensuales y afectuosos: texturas, colores, diseños, prendas hechas a mano, memorias, comunicación intergeneracional, lazos familiares y amistosos. Para la mujer la ropa es parte íntegra de una identidad inculcada durante siglos. Las poetas, inmersas en la cultura de mirada masculina/apariencia femenina encuentran en la indumentaria una materia prima muy suya para elaborar una imaginería propia.

\section{Precursoras}

Para el estudio de la poesía femenina actual es esencial recordar que existe una tradición femenina desde hace siglos, aunque frecuentemente apartada u olvidada. El conocimiento de las obras de las antecesoras contribuye a analizar con mayor precisión y profundidad textos posteriores. El estudio de Amy Kaminsky sobre las referencias al vestir en la obra de María de Zayas (1590-1661) lo confirma. Después de notar que la crítica falocéntrica trivializa las imágenes indumentarias en Desengaños amorosos por suponer que las escritoras solo abordan temas decorativos sin sustancia, Kaminsky refuta la falsa presuposición destacando las contribuciones de Zayas:

By deeming it [feminine culture] worthy of codification in art, Zayas validates and values women's real experience and knowledge. The decorative, symbolic iconographic and narrative functions of clothes [...] show that women's realm of experience is a rich source for literature (Kaminsky, 1988: 391)³.

Dando un salto al inicio del siglo XX sobresale el nombre de Josefina de la Torre (1907-2002). Catherine Bellver señala que la feminización de su mundo poético se manifiesta en referencias a prendas de vestir y al tejer y coser. Esta constelación de referentes se convierte en "instruments of subversion, avenues of self-expression, and the sustances of the reality of confinement to the domestic sphere"4 (Bellver, 2001: 113). Al contrario de algunas de sus contemporáneas, como Concha Méndez (1898-1986), quien hace alarde de vestirse de esquiadora, pilota y nadadora, de la Torre no intenta borrar la diferencia del género señalado por la indumentaria, sino opta por referirse a una ropa femenina tradicional de encajes y bordados. Lo que llama la atención es su forma de engarzar referencias al vestir en poemas que no tratan cuestiones del género sexual. "Mi falda de tres volantes" (Poemas de la Isla, 1930), por ejemplo, es "un grácil juego de recomposición cubista de la realidad según el 'objeto' al estilo de los ultraístas" (Santana, 1989: 16). No existe todavía una historia completa de la imaginería indumentaria en la escritura femenina de España, pero desde los años 1990 la crítica feminista ha aportado contribuciones significativas. Este estudio, enfocado en las poetas de la Generación del 50, participa en esta labor colectiva.

\section{Las codificaciones del vestir en las poetas de medio siglo}

Como umbral al análisis de poemas, señalamos que en 1951 Adelaida las Santas fundó en Madrid, junto a Gloria Fuertes y María Dolores de Pablos, una tertulia literaria de mujeres bautizada con el nombre de

\footnotetext{
3 “Al estimarla (la cultura femenina) digna de la codificación en el arte, Zayas valida y valora la experiencia y el conocimiento reales de las mujeres. Las funciones decorativas, simbólicas, iconográficas y narrativas de la ropa [...] demuestran que la esfera de la experiencia femenina es una fuente de riqueza para la literatura".

4 "instrumentos de subversion, avenidas de autorrepresentación, y la substancia de la realidad del encierro en la esfera doméstica".
} 
"Versos con falda". El nombre y las actividades del grupo constituyen un reconocimiento de la posición marginal de las escritoras y su empeño de participar en el ámbito cultural. Un poema recitado en la tertulia, también titulado "Versos con faldas", ironiza con humor subversivo cómo tendrían que ser las poesías escritas por mujer para que fueran bien vistas, qué ropaje sería lo más adecuado. Los primeros versos establecen el tono brioso:

\section{¿Cómo serán éstas?}

¿Serán faldas cortas?

¿Serán faldas largas?

¿De percal o seda?

¿Lisas o plisadas...? (apud Payeras, 2009: 63)

"Versos con falda", la tertulia y el poema, reconocen implícitamente el impacto de la mirada masculina en la construcción de la identidad femenina y en la relegación de las mujeres a un espacio distante del centro cultural.

No es extraño que las prendas de vestir, tan presentes en la esfera femenina, emerjan en el discurso poético de las escritoras. Lo que es menos esperado es la variedad temática que colectivamente las poetas abordan utilizando la imaginería indumentaria. Para las poetas de la Generación del 50 el abanico temático incluye la metapoesía, denuncias de la injusticia clasista, protestas en contra de límites asfixiantes y en contra de la represión sexual, la autorrepresentación, y la reivindicación de la matrilinealidad.

\section{Vestidos metapoéticos}

La metapoesía de María Elvira Lacaci (1916-1997) enfatiza un antiesteticismo que apuesta por la palabra "sencilla/casi pobre" (Lacaci, 1963: 11). José Luis Cano subraya "el desnudo realismo con que la autora trataba los temas, sometiéndolos a una voluntaria orfandad de galas retóricas" (Cano, 1974: 182). Como Gloria Fuertes, Lacaci desea hablar con claridad para que la entienda el pueblo y los marginados: "Me siento vagabunda de las Letras./Quiero comer mi pan con el mendigo. Beber vino de todos" (Lacaci, 1963: 13). El estilo directo y la escasez de figuras retóricas y tro- pos no disminuyen la fuerza expresiva; al contrario, las figuras presentes, como las imágenes indumentarias, conllevan una compleja síntesis afectiva y conceptual.

Con frecuencia Lacaci emplea alusiones a la ropa para contrastar un estilo esteticista con otro coloquial y directo, categorizado por ella como rebelde. En "La palabra" (Al este de la ciudad, 1963), por ejemplo, la voz poética, dirigiéndose directamente a 'la palabra' refiere a un vestido de tela delicada para expresar su desagrado con el embellecimiento superficial: "A veces,/vas a brotarme de organdí vestida (sin querer/me florece el lenguaje de otros seres)" (Lacaci, 1963: 11). El poema "El traje nuevo" (Humana voz, 1956) de nuevo elabora la imaginería indumentaria para contraponer una poesía 'correcta' y decorativa con otra andrajosa. El sujeto poético reconoce que su manera independiente de escribir crea una apariencia poco presentable ("No. No es correcto. Lo sé,/el presentarme así todos los días./A mi modo. Rebelde"), y propone adaptarse a un estilo refinado: "Voy a vestirme el traje de etiqueta" (Lacaci, 1956: 41). Con ironía sutil los versos finales de "El traje nuevo" reiteran la imposibilidad de conformarse con las "almidonadas frases/con puntillas/y lazos/de colores vistosos” (Lacaci, 1956: 42).

\section{Denuncias de códigos de comportamiento femenino asfixiantes}

María Benyeto (1925-2011), otra figura destacada de la Generación del 50, siempre rechazó los encasillamientos, tanto del género sexual como de los estilos poéticos. En su poesía cuestiona la identidad femenina fosilizada prevalente durante la posguerra española. Tanto el régimen como la iglesia esperaban que la mujer fuera sumisa, servicial, hogareña, dependiente, pudorosa y poco sabia. En "Museo romántico" (Para desconocer la primavera, 1994), por ejemplo, Beneyto alzó la voz para denunciar la desolada inmovilidad femenina. Si el título del poema indica que la dama descrita es del siglo XIX, la primera estrofa confunde el pasado con el presente al localizarla delante del televisor. $\mathrm{Al}$ asomarse a la luz de la pantalla - signo de una abertura al mundo- no ve más que perdurables sombras y oquedades. La segunda estrofa introduce imágenes indumenta- 
rias, inicialmente para recalcar que el modelo de mujer decimonónico es inválido para el presente. Las "románticas blondas" y los abanicos comunican la caducidad de la pasividad y la fragilidad como atributos femeninos, y también del espacio interior privado como única esfera. El color del vestido, negro, sugiere una existencia que equivale a la muerte en vida:

Románticas blondas. Abanicos que huyen

- no abanicos no, son golondrinas

que exhiben plumón y ala- rozan

la fiebre del latido.

Dama en negro (travestida tal vez

de golondrina)

asomada al pequeño barandal del aire

para no ser jamás. (Beneyto, 1994: 30)

La palabra "travestida" introduce la noción de un ser dividido. La apariencia exterior no coincide con quien es en realidad la dama. La golondrina, el ser interior asfixiado, pero potencialmente vital y activo ("plumón y ala"), no logra librarse, y la mujer se queda sola e inmovilizada en la construcción patriarcal del género, una pieza de museo.

Otra poeta que emplea la imaginería indumentaria para hablar de los asfixiantes límites impuestos es Blanca Sarasua (1939), por edad al borde entre la Generación del 50 y la del 70. Sus primeros libros reflejan las consecuencias de haber sido socializada como mujer durante el franquismo. A la edad de cuarenta y cinco años publicó su primer libro de poesía y a partir de entonces iba rompiendo el silencio inculcado en su generación que "siempre habló en voz baja/por los largos corredores del silencio" (Sarasua, 1986: 56). Sarasua explica que para ella la poesía es: "una forma de preguntar, incordiar, constatar que existimos [...] crear un problema [...] que rompa el mundo sumiso y aburrido que hemos creado, en el que nos dicen qué tenemos que hacer, cómo y cuándo" (Ugalde, 2007: 471). En "A una muñeca antigua," utilizando alusiones a la ropa, expresa una sensación de asfixia. El yo poético, como la muñeca, se siente "amortajada de moaré y sombrero" (Sarasua, 1986: 64).
Sarasua crea un espacio poético donde expresar su inconformidad y frustración con la represión sexual de las mujeres. Como señala María Payeras con respecto a la posguerra, "la virginidad es sólo un aspecto de la moral sexual aplicada a la conducta femenina en una sociedad que identifica a la mujer perversa con la mujer sexualmente activa" (Payeras, 2009: 280). En el poema "Una buena pregunta" (Ballestas contra el miedo, 1990) una imagen indumentaria hace transparente el impacto psicológico negativo de la represión sexual: "Después del cuello y hacia abajo, era la nada [...] Generación sin cuerpo/de tristes guantes blancos” (Sarasua, 1990: 29). El sistema semiótico del vestir comunica la conformidad o inconformidad con las normas. Los guantes blancos señalan un comportamiento decoroso, 'correcto'. La personificación, “tristes guantes blancos”, por otra parte, desvela las consecuencias de la obediencia: la vida ensombrecida de las mujeres cuyo deseo erótico se censuraba con más empeño que el del hombre (Payeras, 2009: 278).

\section{Poesía ética: el clasismo}

Francisca Aguirre (Alicante, 1930), otra poeta de publicación tardía y por lo tanto apartada tanto de las antologías de la Generación del 50 como de las de los poetas del 70, publicó su primer libro, Ítaca, en 1972, al cual han seguido nueve tomos. Al intentar definir su poesía Aguirre habla del "sueño de comunicar" y añade que para ella la poesía es también, "como dijo Pablo Neruda, una manera de confesar que he vivido. Siempre he pensado que, para bien o para mal, somos Historia” (Ugalde, 2007: 291). $\mathrm{Su}$ historia personal, velada pero presente en su poesía, son memorias traumáticas de la niñez durante los años de guerra y la posguerra. Aguirre vivió personalmente de niña un exilio en Francia con su familia, luego a los diez años la vuelta a Madrid y a la carencia, y la encarcelación y ejecución de su padre por el régimen franquista. Además de exponer el impacto de la política nacional en la vida íntima, indaga sus experiencias como mujer, un aspecto de su obra que subraya John C. Wilcox: "[S] he provides an antagonistic vision of a woman in the patriarchal Spanish society of the 1960s 
and 1970s. Her gynopoetics challenge the andocentric vision of her culture [...]"5 (Wilcox, 1997: 234).

La elaboración de la imaginería indumentaria sobresale en el poema "Esta vida, hay que ver, qué desatino" (Los trescientos escalones, 1977), una memoria/reflexión sobre la pobreza de la posguerra. Con lenguaje inventivo, ingenioso y coloquial, Aguirre retrata las penurias cotidianas. El texto profundiza la cuestión ética del clasismo al hacer transparente la indiferencia de "los seres más afortunados" frente a los graves apuros económicos de la gente a su alrededor. El clímax del extenso poema —ochenta versos- es una explosión emotiva de los desheredados: "pero a veces, algo que se asemeja al odio/nos corre por la sangre y nos agranda/como un hambre voraz y justiciero" (Aguirre, 1977: 63).

Lo atrayente para nuestro análisis es el uso original de alusiones a la ropa para sintetizar la dura realidad de la posguerra y la complejidad emotiva de soportarla. Las imágenes figuran en dos secciones del poema. La primera, extendida a lo largo de quince versos, combina la descripción con verbos activos en primera persona para expresar tanto las dificultades como el esfuerzo de enfrentarlas.

Esta vida tan remendada,

a la que tantas veces le saqué el dobladillo

para alargarla un poco más,

esta vida que llevo, que mantengo,

a veces (sólo a veces, cuando estoy muy cansada,

o muy triste o muy sola o todo en una vez)

me parece un vestido tan raído,

un traje de segunda mano,

algo que nunca fue estrenado,

algo que usaron otros y que yo, pobre desde siempre,

hundida en la miseria desde siempre,

lavé y planché, cosí, zurcí agujeros

hasta dejarla decentita,

5 "Ofrece una visión antagónica de la mujer en la sociedad española patriarcal de los años 1960 y 1970. Su ginopoética reta la visión androcéntrica de su cultura”. hasta darle un aspecto de decoro

y lucirla con esa dignidad

que sólo son capaces de poseer los pobres,

aquellos que han conocido la carencia

desde mucho antes de nacer. (Aguirre, 1977: 61)

La pobreza impone una vida de trapo, de prendas raídas y remendadas, y siempre de segunda mano. El esfuerzo necesario para seguir adelante es enorme y requiere creatividad. A la vida/vestido se le hace de todo para que sirva: sacar el dobladillo, planchar, lavar, coser y zurcirla. El resultado no es un lúcido traje elegante como llevan las mujeres de la clase privilegiada, sino la dignidad de los pobres. Con un ingenioso discurso indirecto, se reprende a los pudientes a la vez que reivindica las calidades valiosas de los desamparados. La segunda imagen, que reitera la creatividad requerida para sobrevivir, es una americana vieja, tan remendada que es "una obra de arte" (Aguirre, 1997: 63). Sin embargo, algo siempre delata su "aire de recompostura" y su "lustre tan ficticio" (Aguirre, 1997: 63). La hablante se muestra compasiva y desea consolar la vida/tela tan desgastada de los demás. La ingeniosa elaboración de la imaginería indumentaria en "Esta vida, hay que ver . . ." abre lecturas más allá de una condenación del clasismo y la valorización del ingenio de los necesitados. Wilcox, por ejemplo, propone que el poema reafirma la visión no-trascendentalista característica de la obra de Aguirre: "Clearly, Aguirre wants to undermine masculine visions of control, totality, and analytic ratonality: life is not a solider's fort; it's a scrap of cloth [...]"6 (Wilcox, 1997: 240).

\section{El atuendo de la autorrepresentación}

La representación de la mujer en el arte y la literatura occidentales refleja una identidad binaria patriarcal: o santa o bruja. Gradualmente, y en la actualidad a un paso más acelerado, las escritoras adquieren la autoridad literaria para constatar, ellas mismas, quiénes son. Proponen identidades que se ajustan a sus experiencias, sentimientos y sus visiones de

6 "Obviamente Aguirre propone socavar visiones masculinas de control, totalidad y racionalidad analítica”.

UNED. REI, 5 (2017), pp. 47-69

ISSN 2340-9029 
plenitud. Las poetas de la Generación del 50 aceptan el reto de abrir un espacio textual para la autorrepresentación y con frecuencia recurren a la imaginería indumentaria para explorar y formular identidades.

"La falda" (Las dulces viejas cosas, 2001) es un poema característico de la obra de Pino Betancor (1928-2003): emotivo, sensual y perspicaz. Una sensación de serena alegría fluye entre reflexiones sobre la vejez y el género. La poeta relaciona la autorrepresentación con el ocaso de la mirada masculina. "La falda" narra cómo un día el yo hablante escoge qué ponerse, consciente de cómo reaccionará a la selección el tú interlocutor, quien, por indicaciones textuales, es el esposo. La espina dorsal estructural del poema contrapone dos categorías de ropa: la vieja cómoda, que consiste en una falda "de tela desvaída, tantas veces lavada, usada" y una blusa "gastada", y la elegante, prendas guardadas en el gran armario: "más preciadas./Oscuros terciopelos,/suaves sedas de Italia” (Betancor, 2001: 11,14).

La ropa vieja introduce en el texto el mundo cotidiano de yo poético, lo que le es familiar y cómodo, y se convierte en signo de la autorrepresentación. La falda y la blusa son amigas de la protagonista, y no sólo por el uso prolongado. La forma en que se adaptan al cuerpo indica una relación íntima, como si fueran parte de su ser. La blusa "ofrece su caricia más íntima/a mis senos", y la falda:

\section{se ciñe a mi cintura}

tan impalpablemente,

que casi ni la siento resbalar

suavemente, rozando mis caderas. (Betancor, 2001: 11)

Es de notar que las dos categorías de prendas, las dulces viejas y las lujosas del armario, inducen reacciones contrarias en el 'tú. La blusa provoca burlas: "Y esa blusa, gastada/de la que tú te ríes/cuando me la ves puesta" (Betancor, 2001: 11). En cambio, los vestidos suntuosos, con la capacidad de transformar a la mujer en espectáculo, inducen una reacción inversa: "Los hermosos vestidos/con que te gusta verme" (Betancor, 2001: $14)$

Una razón que motiva al sujeto poético a optar por sus prendas amigas es la edad avanzada, inferida por la metonimia "la dulce penumbra de la tarde", que exige comodidad, pero las últimas líneas enfatizan otra razón: el fin de la mirada femenina desdoblada. El sujeto poético le pide perdón al tú interlocutor para luego asumir con alegría una identidad libre de la mirada masculina:

\section{Perdóname que elija}

entre el placer de verme

hermosura ante tus ojos,

esta humilde alegría

de verme como soy. (Betancor, 2001: 14-15)

Si la mirada erótica y vigilante masculina determina la identidad femenina, como propone Mulvey, entonces ponerse la vieja falda es un acto que repercute en las bases patriarcales, trasfiriendo a la mujer la autoridad de autorrepresentarse (Mulvey, 1999: 837).

Además de deconstruir la mirada controladora, el poema proyecta una visión erótica femenina libre de jerarquías. Alicia Ostriker explica que el ardor femenino "has been chained to submissiveness. To love, for a woman, has meant to yield, to 'give herself"'7 (Ostriker, 1986:165). Ostriker añade que en la poesía escrita por mujeres se expresa un anhelo intenso por alcanzar una relación amorosa no definida por el dominio y la subordinación, sino basada en la mutualidad, la continuidad, el tacto (Ostriker, 1986: 165). Luce Irigaray relaciona la visión erótica imaginada por las mujeres con los papeles contrariados de los sentidos de la vista y el tacto: "The supremacy of seeing has too often transformed our amorous relations into a sort of master-slave sruggle for subjecting the other through looking at"8 (Irigaray 2011: 137). Irigaray proyecta las consecuencias de favorecer al tacto más allá del contexto erótico femenino: "We have to discover a new relationship with knowledge which takes into account the importance of

\footnotetext{
7 "ha estado encadenada a la sumisión. Amar para una mujer, ha significado ceder, "entregarse"”.

8 "La supremacía de la vista ha transformado demasiado frecuentemente nuestras relaciones amorosas en una especie de lucha amo-esclavo por someter al otro por medio de mirar".
}

UNED. REI, 5 (2017), pp. 47-69

ISSN 2340-9029 
touch in the constitutions of our own individuation and our relationships with other(s)"9 (Irigaray, 2011: 138).

En "La falda" la presencia de las telas —los hilos desvaídos, la suavidad de las prendas viejas, y la sensación deliciosa del terciopelo y la seda- cambia el balance de los sentidos a favor del tacto. El contacto de la ropa con la piel —el roce entre la falda y las caderas y la forma en que la blusa acaricia los senos- lo acentúa aún más. La experiencia táctil con las "amigas de mi cuerpo" (Betancor, 2001: 12) es placentera físicamente y gratificante emocionalmente, y sugiere que la autorrepresentación en el poema abarca una forma distinta de relacionarse eróticamente. El dominio de la vista se transforma en la mutualidad del tacto.

El poema "Con tacones altos" (Al este de la ciudad) de María Elvira Lacaci representa otra vertiente de la autorrepresentación. El poema se aleja de la temática del género sexual para centrarse en un estado de ánimo angustioso. El sujeto poético se sincera consigo mismo rehuyendo disfraces que encubran el ser íntimo. El lenguaje figurativo indumentario comunica la aspiración de quitarse las máscaras y enfrentarse con el dolor, pero además tiene una consecuencia secundaria: reflejar el fuerte arraigo de la mirada desdoblaba femenina y el poder de la mirada masculina de transformar a las mujeres en objetos sexuales.

El yo hablante describe en primera persona cómo se vestía anteriormente, dejando entre líneas su inconformidad con la moda:

Y yo llevaba un gorro

muy moderno. Parecía

una extraña cazuela.

Unos tacones leves y muy altos.

Un abrigo atrevido.

Unos guantes y un bolso de color avellana.

Los labios y los ojos pintarrajeados. (Lacaci, 1963: 33)

9 "Tenemos que descubrir una nueva relación con un conocimiento que tenga en cuenta la importancia del tacto en la constitución de nuestra propia individualización y de nuestras interrelaciones con el otro".

UNED. REI, 5 (2017), pp.
La reacción de la gente de la calle a su estilosa vestimenta deja constancia de que la mirada se diferencia por el género:

No debía de ir mal.

Las mujeres

volvían la cabeza

para mirar la hechura del abrigo.

Los hombres ... (Lacaci, 1963: 33)

Las mujeres, sin duda subconscientemente sensibles a cómo las enjuiciarían los hombres, aprueban su apariencia, sobre todo la hechura del abrigo. La reacción de los hombres se expresa con una elipsis, indicando el tabú de hablar en voz alta de la sexualidad durante el apogeo de la represión femenina en la España de posguerra. La mirada masculina que transforma a la mujer en objeto sexual queda aludida de forma discreta.

El proceso de autoconocimiento requiere una franqueza tal que no valen los ridículos disfraces: "Pero yo,/bajo la piel y aquella vestidura de comparsa,/llevaba otro ropaje de un tejido muy denso. Era de angustia" (Lacaci, 1963:34). Para expresar la soñada liberación del doloroso desasosiego (el "tejido muy denso"), igualmente recurre a la vestimenta, escogiendo ropa que permitirá el libre movimiento: "Y añoré/mi pelo suelto, mis zapatos bajos,/mi abrigo deportivo" (Lacaci, 1963:34). En el proceso de expresar la pujante angustia íntima, el poema deja entrever el poder de la mirada patriarcal y reivindica el mundo femenino de la ropa como fuente de la imaginería poética.

"Godiva en blue jean" (El mundo de M. V., 1978) de María Victoria Atencia (Málaga, 1930) es un poema-espejo en que la protagonista Godiva/yo hablante se contempla. El proceso de autoconocimiento expuesto contrapone y entrelaza dos imágenes distanciadas por unos nueve siglos:

Cuando sobrepasamos la raya que separa

la tarde de la noche, pondremos un caballo

a la puerta del sueño $y$, tal lady Godiva,

puesto que así lo quieres, pasearé mi cuerpo

- los postigos cerrados- por la ciudad en vela...

No, no es eso, no es eso; mi poema no es eso. 
Sólo lo cierto cuenta.

Saldré de pantalón vaquero (hacia las nueve

de la mañana), blusa del "Long Play" y el cesto

de esparto de Guadix (aunque me araña a veces

las rodillas). Y luego, de vuelta del mercado,

repartiré en la casa amor y pan y fruta. (Atencia, 1984: 79)

La leyenda de Lady Godiva se basa en una figura histórica inglesa del siglo XI. En la década de los 1970 en España la novedad de los blue jean se incorpora en el ropero de las mujeres, lo cual lleva a suponer que la segunda mujer es de esa época, como la autora misma. La división del poema en dos partes, cinco versos cada una más una transición central, acentúa la yuxtaposición de dos identidades.

La primera parte se enfoca en la leyenda de Lady Godiva, quien por apoyar a la gente necesitada del pueblo de Coventry, le pidió a su esposo, el conde Leofric, que bajara los impuestos. Éste contestó que sí con la condición de que ella se paseara desnuda a caballo por las calles del pueblo. Godiva aceptó el reto, pero, por su ingeniosa creatividad, sin sacrificar el pudor. Se cubrió la desnudez con sus largos y abundantes bucles y acordó con el pueblo que cerrara las contraventanas. El yo hablante, junto con los lectores, entra en un mundo onírico ("noche", "la puerta del sueño") de leyendas y mitos que guardan y transmiten representaciones culturales de la mujer.

El poema subraya que el paseo por el pueblo no depende de la voluntad de Godiva sino del Otro: "Puesto que así lo quieres". El tú interlocutor es ambiguo, podría ser, por ejemplo, el yo poético con una identidad fragmentada. Sin embargo, por el contexto de la leyenda, es probable que sea el esposo, una presencia sugerente de la mirada masculina. Otro elemento que prevalece de la época legendaria es la práctica social de ver el cuerpo femenino como objeto sexual. El simbolismo del caballo, que enmarca la escena ("pondremos un caballo a la puerta del sueño"), introduce la presencia del deseo impetuoso, la virilidad y la sexualidad (Julien, 1996: 207). La primera estrofa cierra con hincapié en la mirada: "Por la ciudad en vela..... A pesar de "los postigos cerrados" ella "sigue percibiendo los ojos que le acechan" (Thompson, 2002). Retazos de la historia del poder de la mirada masculina asoman en este nebuloso retrato de Lady Godiva.

Los versos de transición, "No, no es eso, no es eso; mi poema no es eso. Sólo lo cierto cuenta", desautorizan la imagen de la Godiva mítica y el mundo legendario que habita, pero en vez de borrarla completamente la poeta opta por vestirla con ropa y atributos relacionados con una mujer contemporánea (Thompson, 2002). La transición separa las dos imágenes, pero igualmente abre una puerta por la cual el yo poético pasa del pasado mítico a la realidad del presente. Ahora se viste a la moda y de forma cómoda, vaqueros y una blusa "long play". Esta mujer de la actualidad sale por voluntad propia, no por obedecer al Otro, y el cuerpo ya no es un espectáculo a merced de miradas lascivas o críticas. Es de día, no la hora de la entrada de la noche, y la luz de la mañana parece vigorizar a la protagonista mientras desempeña sus quehaceres en el mercado.

En una lectura inicial se podría concluir que "Godiva en blue jean" refuta una anticuada identidad patriarcal de la mujer para luego ofrecer otra, la de una mujer contemporánea con mayor libertad. Pero en este texto, como en la mayoría de Atencia, la aparente sencillez engaña. La eficacia poética reside en la inestabilidad de significaciones que niega una sola interpretación. En una relectura sobresalen las semejanzas, no las diferencias, entre Godiva y yo poético contemporáneo, quienes, por la clarificación "tal lady Godiva," se (con)funden desde el inicio. Las dos salen para proveer a quienes aman para luego repartir "esas substancias esenciales para el bienestar de una familia y comunidad" ("amor y pan y fruta"), (Persin, 1998: 119). La reiteración del acto de amoroso cuidado en épocas temporalmente tan distanciadas realza el valor de un papel íntimamente ligado a la tradicional "existencia, posición y función de la mujer en la sociedad" (Persin, 1998: 119). Habría que notar, sin embargo, que a pesar de la evidente satisfacción e incluso gozo con que realiza los quehaceres el yo poético actual, existe un punto de frustración. El cesto de la compra diaria, metonímicamente las obligaciones domésticas, puede hacer daño: "(y el cesto/de esparto de Guadix (aunque me araña a veces las rodillas)". Las dos figuras son parecidas en otro respecto: la creatividad. Godiva ingenia una fórmula para lograr su meta: aceptar el reto atrevido de su marido, 
pero sin humillarse, y la creatividad del yo poético contemporáneo, como autorrepresentación de la autora, se manifiesta en su labor literaria, en el mismo poema que estamos leyendo. La poeta misma afirma que las dos Godivas, como las dos figuras en el poema "Marta y María" "no dejan de ser el desdoblamiento de un 'yo' único” (Atencia, 2009: 39).

Tampoco se trata simplemente de o diferencias o semejanzas. Para captar las sutilezas hay que fijarse en la tensión entre la figura mítica y la contemporánea. Con el "No, no es eso" se deconstruye la mujer definida y limitada por la mirada masculina, pero a la vez se reconocen sus calidades valiosas. En esta perspicaz autorrepresentación, Atencia reconoce la presencia del pasado en el presente. La identidad de la mujer es un proceso, un texto, un cuerpo, cuya indumentaria requiere reiteradas y continuas puestas al día.

\section{Arropando la matrilinealidad}

Un paso esencial en la autorrepresentación es virarse hacia el pasado y reclamar una tradición cultural femenina abandonada en los márgenes. Desde mediados del siglo XX la voz colectiva de las poetas españolas va narrando una herencia matrilineal. El rescate y la reinterpretación de olvidadas antecesoras, diosas míticas, profetas y brujas, mujeres bíblicas e históricas y figuras de la literatura y del arte -Eva, Penélope, Salome, Ofelia, Lady Godiva - visibiliza una continuidad cultural femenina, otorgándola legitimidad y autoridad. La recuperación de una herencia matrilineal no se limita a figuras cultas; también tiene una cara cotidiana e íntima, manifiesta en poemas dedicados a indagar los lazos inquebrantables e intensos que unen a las mujeres. Las poetas exploran, sobre todo, las relaciones hija-madre-abuela. El punto de partida suele ser autobiográfico pero los poemas adquieren dimensiones simbólicas y metafísicas. Temporalmente se sitúan en distintos momentos de la trayectoria vital, desde la niñez hasta la muerte, y espacialmente predomina la domesticidad. El perfil de la madre tiene diferentes vertientes: una fuente de afectividad y apoyo, una persona admirable por su actividad, esfuerzo y constancia, y como anciana o como memoria. Se corta el cordón umbilical pero, según la perspectiva de las poetas, jamás se renuncia al vínculo hija-madre. Es un elemento inconfundible del ser íntimo.

La obra de Elsa López (1943) ejemplifica la recuperación del legado matrilineal íntimo en poemas dedicados a la madre y a la abuela, cuya fuerza expresiva se intensifica con la imaginería indumentaria. López destaca la presencia en su poesía de "paisajes interiores" y "descripciones idealizadas por la memoria", y añade que son pretextos "para reconocerme" (Ugalde, 2007: 518). Una de las intimidades que descubre y revela es el enorme espacio que ocupa la madre y la abuela en el "territorio íntimo del alma" (Ugalde, 2007: 518). En "Recuerdo aquella imagen de la abuela..." (El viento y las adelfas, 1973) la autora transforma un recuerdo del vestido de la abuela en una imagen de vitalidad imperecedera: "El suave balanceo de los lunares blancos/camino del cantero" (López, 1973: 25), y en "El armario" (Cementerio de Elefantes, 1992) la voz lírica, al abrir las puertas del guardarropa, descubre la esencia inalterable de su herencia matrilineal: "y yo supe que allí estaba escondida el alma de la casa,/el olor de la abuela recién planchado,/la falda de la madre rozando paredes/sus zapatillas blancas,/y el beso que le daba las noches de tormenta" (López, 1992: 38).

En "La madre adoptó la postura..." (Del amor imperfecto, 1987) el dolor de la ausencia física de la madre se atenúa con la creación poética de un tiempo monumental que la transforma en una presencia eterna, casi mítica.

La madre adoptó la postura

sin peso

de las madres,

el vestido de plata

- plateado-

como el vuelo transparente de un ave.

Y se quedó encerrada

en el fanal del tiempo

haciendo de columna,

de brazos,

de barrotes.

Lo demás no importaba. (López, 1987: 27) 
La elevación de la madre biográfica al nivel heroico depende de la sutil y fluida transformación textual de la madre con su "vestido de plata" en monumental columna luminosa. La clarificación de que el "vestido de plata" es más precisamente "plateado" elimina el peso del metal, sin eliminar la luminosidad. La ligereza, ya aludida en la segunda línea ("sin peso") se refuerza con la clarificación permitiendo una metamorfosis de la imagen de la madre en "vuelo transparente de un ave", con sus connotaciones de ascenso vertical, ser enaltecido y espíritu elevado. Las líneas 7-9 igualmente señalan una metamorfosis. Esta vez la luminosidad del vestido deviene un fanal, brillante y erecto como un prodigioso monumento. La luz implica lo sagrado, la veneración, y también la sabiduría de repartir el afecto ("brazos") y la protección ("barras"). Para la hija la relación es esencial: "y lo demás no importaba".

"Color de rosa" (Los sueños, 1976) de María Victoria Atencia, otra revalidación de la matrilinealidad, expresa una intensa emoción agridulce provocada por la presencia de la madre que se desliza hacia la muerte. La anciana enferma recupera momentáneamente la ilusión juvenil al ponerse, con la ayuda del sujeto lírico/hija, un querido traje viejo de color rosa pálido. Aquí la alusión a la prenda le sirve a Atencia para comunicar con precisión la relación afectiva hija-madre en un momento determinado de la trayectoria vital de ambas. El nombrar objetos de la indumentaria femenina - el traje de color rosa, el collar de azabache y la camisa de malteado georgé- expresa de forma original las sutilezas de una relación que parece estrecharse y dulcificarse con la vejez de la madre (Atencia, 1984: 56).

\section{Conclusión}

Ann Rosalind Jones, en su estudio de la lírica amorosa europea escrita por mujeres entre 1540 y 1620, llega a la siguiente conclusión: "The more I read of their lyrics, the more I recognized that they had found ways to maneuver within the chastity-silence equation, men's ownership of education and publishing, and the masculine perspective built into erotic conventions"10 (Jones, 1990: 2). Lo mismo se podría concluir sobre la ela-

10 "Cuanto más leo su lírica, más reconozco que encontraron cómo maniobrar dentro boración de la imaginería indumentaria por las poetas de la Generación del 50. Encontraron cómo maniobrarse dentro de una cultura social que las transformaba en objeto visual. La norma femenina opresiva de mostrarse, marcada por la apariencia física, sobre todo por la indumentaria, deviene caudal expresivo. Las prendas del ropero sirven tanto para desautorizar la mirada controladora como para legitimar la esfera femenina; también la imaginería indumentaria dota de originalidad la autopresentación y la expresión de preocupaciones metapoéticas y sociales.

Recibido: $4 / 2 / 2017$

Aceptado: 27/4/2017

\section{Referencias bibliográficas}

Aguirre, Francisca (1977), Los trescientos escalones, San Sebastián: Caja de Ahorros Provincial de Guipúzcoa.

Atencia, María Victoria (1984), Ex Libris, Madrid: Visor. --- (2009), El oro de los trigres, Belamádena: e.d.a. libros.

Barnes, Ruth y Eicher, Joanne B. (1993), Dress and Gender. Making and Meaning, Providence: Berg.

Bellver, Catherine G. (2001), Absence and Presence. Spanish Women Poets of the Twenties and Thirties, Lewisburg: Universidad de Bucknell.

Beneyto, María (1994), Para desconocer la primavera, Madrid: Torremozas. Berger, John (1972), Ways of Seeing, London: British Broadcasting Corporation and Penguin Books.

Betancor, Pino (2001), Las dulces viejas cosas, Las Palmas de Gran Canaria: El Museo Canario.

de la fórmula castidad-silencio, con los hombres como propietarios de la educación, de la publicación y de la perspectiva masculina de las convenciones eróticas".

UNED. REI, 5 (2017), pp. 47-69

ISSN 2340-9029 
Cano, José Luis (1974), Poesía española contemporánea. Las generaciones de posguerra, Madrid: Guadarrama.

Irigaray, Luce (2011), "Perhaps Cultivating Touch Can Still Save Us", SubStance. A Review of Theory \& Literary Criticism, 40.3, pp. 130-140.

Julien, Nadia (1996), The Mammoth Dictionary of Symbols: Understanding the Hidden Language of Symbols, New York: Carol and Graf Publishers.

Jones, Ann Rosalind (1990), The currency of Eros, Bloomington: Universidad de Indiana.

Kaminksy, Amy Katz (1988), "Dress and Redress: Clothing in the Desengaños amorosos de María de Zayas y Sotomayor", Romantic Review, 79.2, pp. 377-391.

Lacaci, María Elvira (1956), Humana voz, Madrid: Rialp. Col. Adonais.

--- (1963), Al este de la ciudad, Barcelona: Flors.

López, Elsa (1973), El viento y las adelfas, Tenerife: Régulo.

--- (1987), Del amor imperfecto, Melilla: Rusdir.

--- (1992), Cementerio de elefantes, Islas Canarias: Gobierno de Canarias.

Mulvey, Laura (1999), "Visual Pleasure and Narrative Cinema”, en Film Theory and Criticism: Introductory Readings, ed. de Leo Braudy y Marshall Cohen, New York: Universidad de Oxford, pp. 833-44.

Ostriker, Alicia Suskin (1986), Stealing language. The emergence of Women's Poetry in America, Boston: Beacon Press.

Payeras Grau, María (2009), Espejos de palabra. La voz secreta de la mujer en la poesía española de posguerra (1939-1959), Madrid: Universidad Nacional de Educación a Distancia.

Persin, Margaret (1998), "El canon un tiro más (sin apuntar) de cañón: el lugar y la posición de poesía femenina en la España del siglo XX”, en $L a$ poesía de María Victoria Atencia: un acercamiento crítico, ed. de Sharon Keefe Ugalde, Madrid: Huerga y Fierro, pp.109123.

Santana, Lázaro (1989), "Introducción", en Torre, Josefina de la, Poemas de la Isla, Islas Canarias: Gobierno de Canarias, pp. 3-16.
Sarasua, Blanca (1986), El cerco de los pájaros, Bilbao: Imprenta Amado. --- (1990), Ballestas contra el miedo, Álava: Diputación Foral de Álava.

Thompson, David R (2002), "Cambiar de vestuario a Lady Godiva: la revisión de mitos en la poesía española contemporánea escrita por mujeres”, Espéculo. Revista de Estudios Literarios, 22, Universidad Complutense de Madrid. [Consultado el 11 noviembre 2016]: <http://www.ucm.es/info/ especulo/numero22/godiva.html>.

Ugalde, Sharon Keefe (2007), En voz alta. Las poetas de las generaciones de los 50 y los 70, Madrid: Hiperión.

Wilcox, John C. (1997), Woman Poets of Spain, 1860-1990, Urbana: Universidad de Illinois. 